\title{
Article \\ Deterioration of Sandstone in the Historical and Contemporary Sea Walls upon the Impact of the Natural and Man-Made Hazards
}

\author{
Rina (Irena) Wasserman
}

check for updates

Citation: Wasserman, $\mathrm{R}$

Deterioration of Sandstone in the Historical and Contemporary Sea Walls upon the Impact of the Natural and Man-Made Hazards. Appl. Sci. 2021, 11, 6892. https://doi.org/ 10.3390/app11156892

Academic Editor: Chiara Giosuè

Received: 14 November 2020

Accepted: 12 January 2021

Published: 27 July 2021

Publisher's Note: MDPI stays neutral with regard to jurisdictional claims in published maps and institutional affiliations.

Copyright: (C) 2021 by the author. Licensee MDPI, Basel, Switzerland. This article is an open access article distributed under the terms and conditions of the Creative Commons Attribution (CC BY) license (https:// creativecommons.org/licenses/by/ $4.0 /)$.
Department of Conservation of Sites and Monuments, Western Galilee Academic College, POB 2125, Acre 24121, Israel; rinaw@edu.wgalil.ac.il

\begin{abstract}
The contemporary sea walls built in the pedestrian seashore zone in the City of Acre, Israel, were sided with porous calcarenite sandstone, so-called 'kurkar'. Kurkar stone has been broadly used as a durable building material in Acre and Jaffa, the Eastern Mediterranean offshore cities, since ancient times. Therefore, the contemporary urban architectural plans obligate kurkar siding in the modern structures erected beside the Old City of Acre. However, a rapid deterioration of kurkar siding had occurred in the contemporary sea walls during only a few years. In contrast, the Historic walls built of kurkar dimensional stone have been still sound. The current study has evaluated the factors and causes of kurkar deterioration in the modern seawalls. It was revealed that the main reason for deterioration was adhering the kurkar siding with cement mortar and the next exposure of adhered siding to the humid and salt-enriched offshore environment with high air pollution.
\end{abstract}

Keywords: Sandstone; siding; sea wall; kurkar; deterioration; weathering; Portland cement mortar

\section{Introduction}

Porous calcarenite sandstone, kurkar was used to siding the contemporary concrete sea walls erected in the Panorama offshore promenade (The Panorama promenade is placed along the Mediterranean coast of Acre City, northern to the margins of the Old City, Figure 1. The Panorama was designed in 2002 as a sequence of the historic sea walls of Acre and has been used as an offshore pedestrian promenade since 2005.) in Acre, Israel (Figure 1). Kurkar siding plates were adhered with Portland cement mortar to the concrete walls. Curkar sandstone has been broadly used in Acre and Jaffa, the Eastern Mediterranean offshore cities, since ancient times. This local stone has always had a reputation of durable building material. Therefore, the contemporary urban architectural plans in the modern City of Acre obligate kurkar siding in the contemporary structures erected beside Acre's Old City.

As was published elsewhere, Israel calcareous sandstone is a strongly anisotropic material [1]. Anisotropy is determined as a petrophysical characteristic of natural stones that describes their quality and soundness against decay upon the impact of various harmful agents, such as water, salinity, air pollution, etc. [2]. Anisotropy of rocks' physical properties is mostly due to specific microstructural characteristics, such as the aligned grain fabric, crystallographically preferred orientation within the grains, or the void space's geometry [3].

\subsection{Historical Background of the Place}

Acre is one of the ancient continuously inhabited sites in Israel. It had been mentioned in documents since the end of the 14th century BC [4-6]. During the Hellenistic and Roman periods (4th century BC-5th century AC), the Phoenician City of Acre was known as Ptolemais [7]. As mentioned in the New Testament, Ptolemais was one of the stops on Paul's final return to Jerusalem [8]. Around 1170 AC, Acre became the main port in the 
Crusader kingdom of Jerusalem. The Crusaders called the city "Saint-Jean d'Acre" [9]. The historic sea walls were constructed here in the Crusader Period (1099-1291).

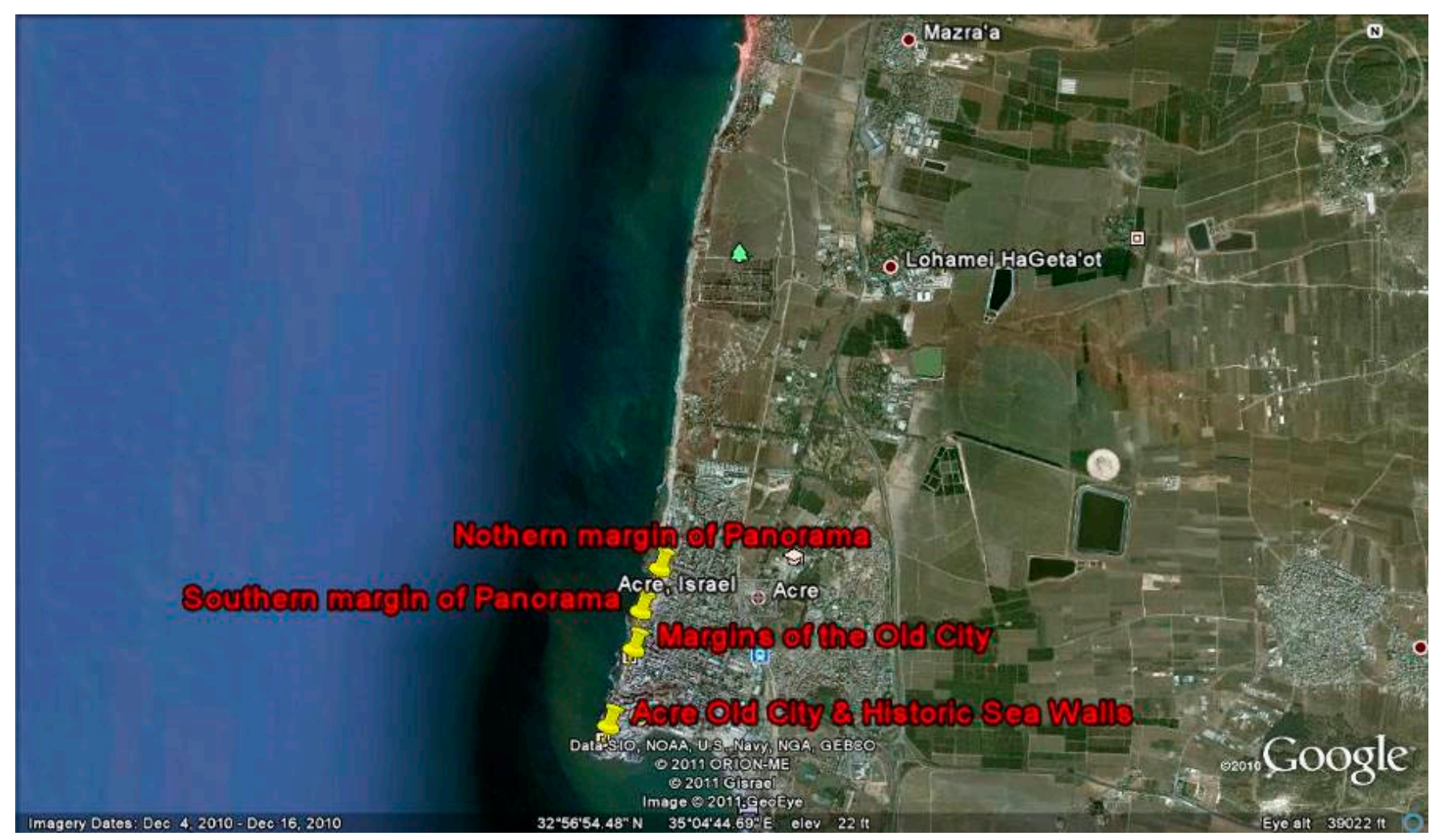

Figure 1. Google Earth Image of Acre coastal zone.

However, Mameluks (Muslims) destroyed the Crusader city to foundations after the Siege of Acre (1291), although the City was defended by two lines of thick walls and twelve towers down. Between the 16th and 20th cc., Acre was under the rule of the Ottomans. In the 18th century, Ottomans utilized the Crusader walls' remnants as a foundation for erecting their walls (1750-1840). The Old City's Historic walls were constructed by the methods particular for the Ottoman architecture of that historical period. Initially, the Wall was thin: its height was 10 to $13 \mathrm{~m}$ and its thickness-only one meter. In 1799, these walls survived the sea attacks of Napoleon's troupes during his Egyptian campaign. Thus, a heavy land defense wall was built north and east to the City in 1800-1814. In years 1918 to 1947, the Citadel of Acre was used by the British mandate as a prison. During the Independence war of 1948, Acre was besieged by Israeli forces. Today, Acre is populated by about 50,000 inhabitants. In 2001, the Old City of Acre was designated by UNESCO as a World Heritage Place.

\subsection{Materials and Construction Methods Used in the Panorama Sea Walls}

Following the ICOMOS and UNESCO decisions and recommendations on the establishment of buffer zones for setting the heritage structures, sites, and areas, Acre's municipality has adopted the Master Plan, including the development of the buffer areas. According to the Master Plan, the buffer zone's contemporary structures should have an appearance esthetically compatible with the Old City of Acre's historic look. The erection of the modern Panorama walls began in 2001 and ended in 2004. The Historical Sea Walls, Figure 2, were built of the dimensional sandstone termed "kurkar," which is a porous aeolian calcarenite $[1,10]$. Thus, external siding made of kurkar sandstone has been implemented in the contemporary Panorama Sea Walls, which have been built as vertical concrete walls, Figure 3 . The concrete used in these walls was ready-mix concrete (w/c 
ratio of 0.5 ). The characteristic compressive strength of the concrete at the age of 28 days was $43 \mathrm{MPa}$. The walls were cast in situ against sandstone veneer siding. The design scheme of a stone veneer is shown in Figure 4. The stain-steel grid was anchored to the wall after maturing the concrete. They filled a gap between a stone veneer and the wall with the cement-based mortar afterward. The porous sandstone siding was joined with the steel grid by hooks.

The project's design specifications have required a nominal thickness of $150 \mathrm{~mm}$ for sandstone siding, five times more than the minimum requirements detailed in SI 2378 [11]. This thickness was supposed to be reliable enough for minimizing the harmful impact of the severe offshore conditions on the steel anchors. The contractor carried out some tests of the physical and mechanical features of the used kurkar sandstone to check whether the kurkar sandstone meets the requirements of SI 2378. The results of the physical properties are summarized in Table 1 . These results obviously show that the kurkar stone failed to meet any minimal requirements of SI 2378. However, the average modulus of rupture was high. Thus, the project's supervisors decided to continue with siding made of this porous kurkar stone.

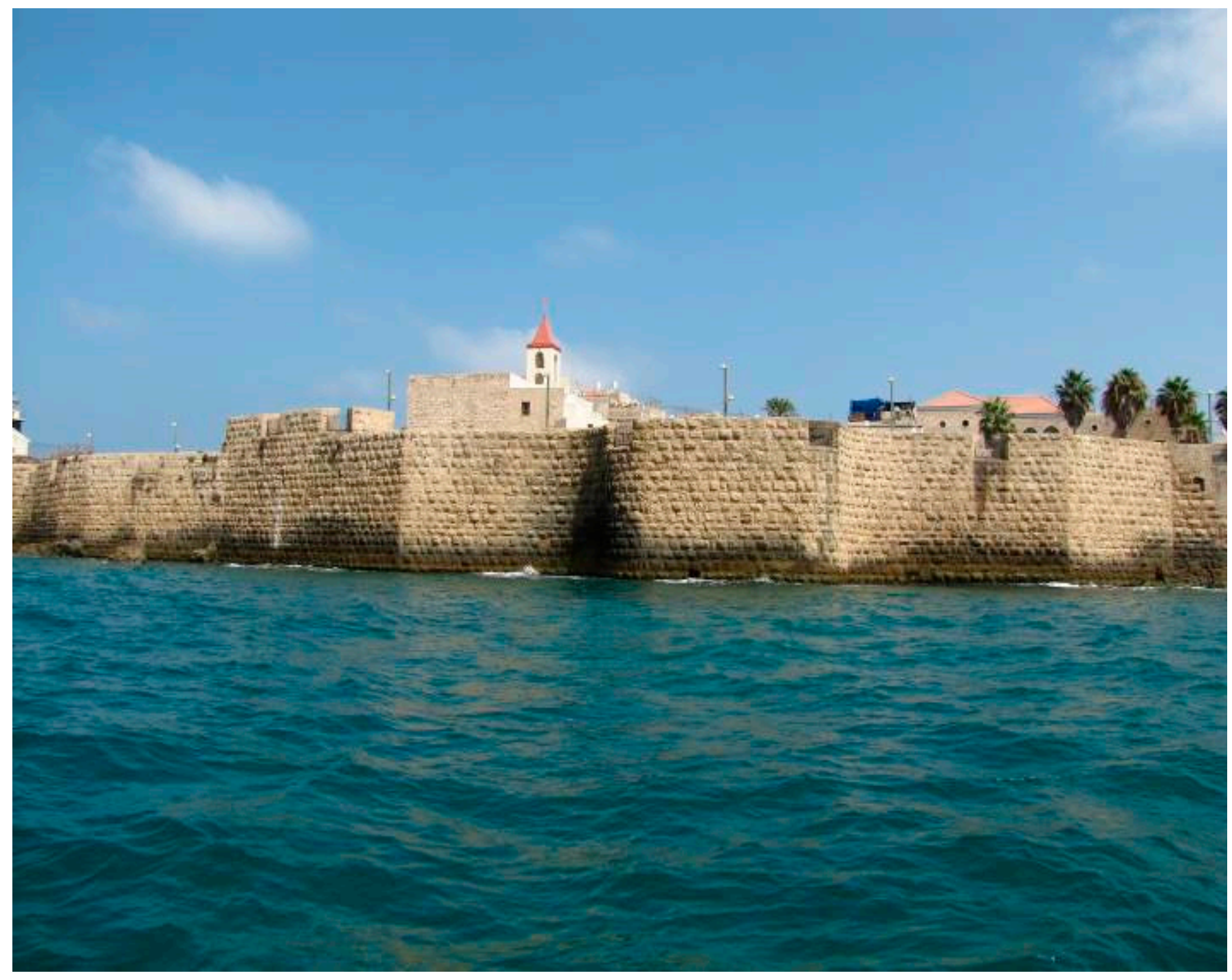

Figure 2. Historic sea wall in Acre. Captured by author on 27 November 2018. 


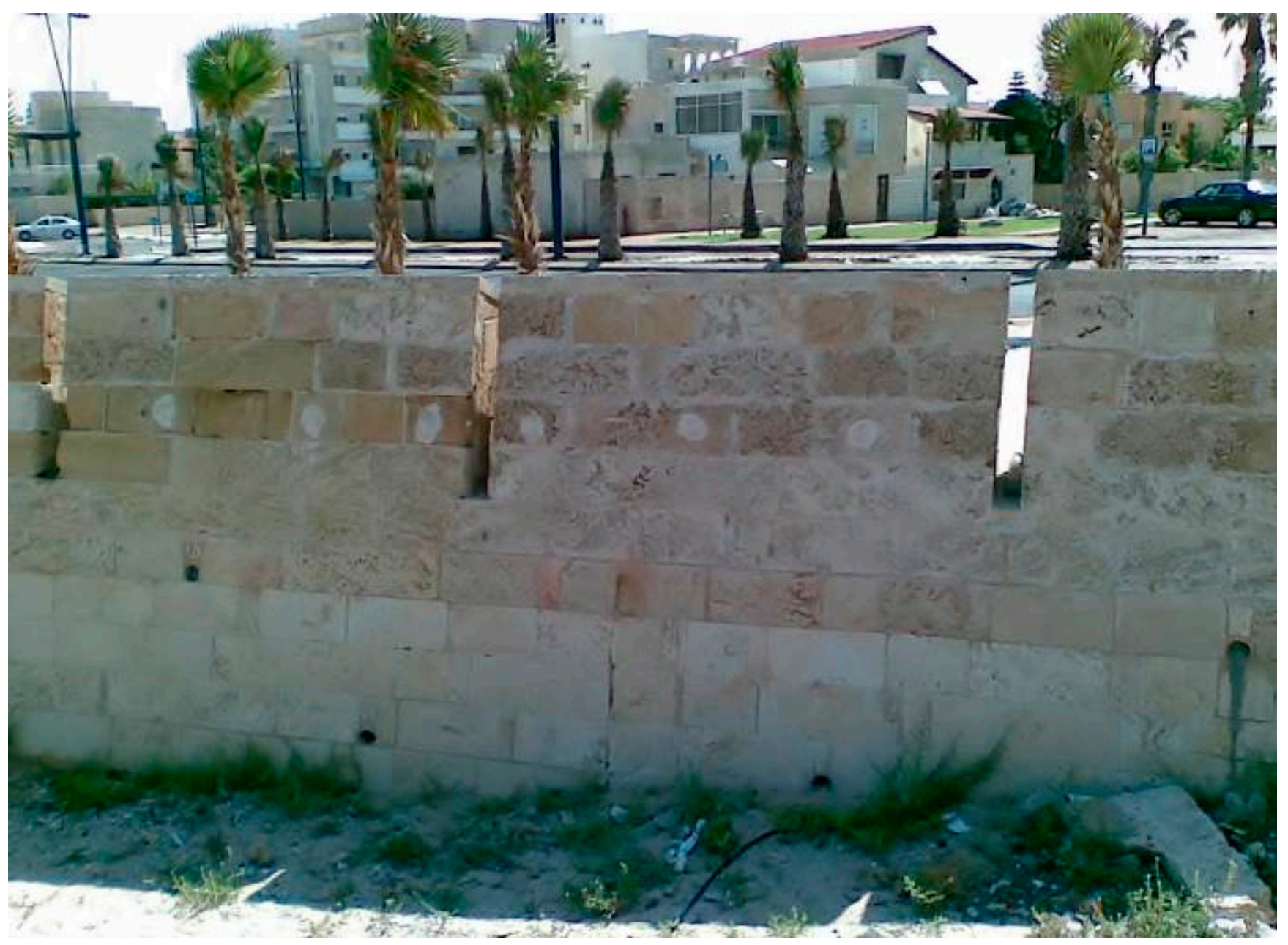

Figure 3. Panorama Sea Wall in Acre. Captured by the author on 27 November 2018.

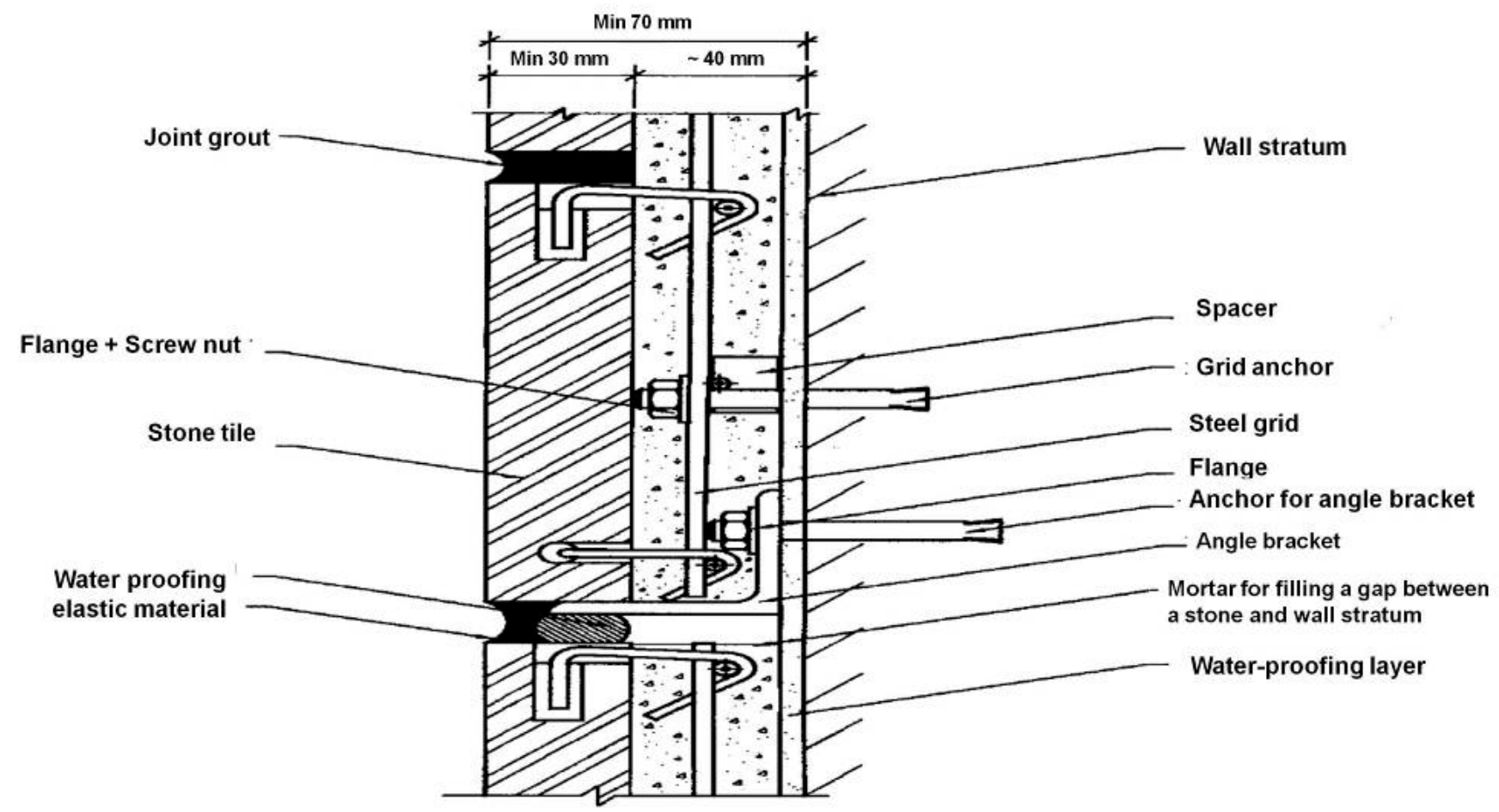

Figure 4. Design of stone veneer, according to [11]. 
Table 1. Properties of original kurkar sandstones used in the Panorama Sea Walls.

\begin{tabular}{ccccccc}
\hline Property & $\begin{array}{c}\text { Minimal } \\
\text { Value }\end{array}$ & $\begin{array}{c}\text { Maximal } \\
\text { Value }\end{array}$ & Average & $\begin{array}{c}\text { Standard } \\
\text { Deviation }\end{array}$ & $\begin{array}{c}\text { Requirements } \\
\text { for Average } \\
\text { Value [11] }\end{array}$ & Test Method \\
\hline Bulk density, kg/m & 1850 & 2120 & 2010 & 106 & $\geq 2500$ & $\begin{array}{c}\text { ASTM C97-18 } \\
\text { [12] }\end{array}$ \\
\hline $\begin{array}{c}\text { Total water absorption, } \\
\text { mass \% }\end{array}$ & 3.4 & 8.64 & 6.1 & 1.6 & $<2$ & $\begin{array}{c}\text { ASTM C97-18 } \\
{[12]}\end{array}$ \\
\hline $\begin{array}{c}\text { Capillary water } \\
\text { absorption, g per m } \\
\text { per hour }\end{array}$ & 2400 & 2680 & 2600 & 55 & $<500$ & $\begin{array}{c}\text { EN 1925-1999 } \\
{[13]}\end{array}$ \\
\hline $\begin{array}{c}\text { Modulus of rupture, } \\
\text { MPa }\end{array}$ & 2.7 & 8.6 & 4.9 & 1.7 & $>3$ & $\begin{array}{c}\text { ASTM } \\
\text { C99-2000 [14] }\end{array}$ \\
\hline
\end{tabular}

\section{Defects Appeared in the Panorama Sea Walls}

The numerous defects in the stone veneer have appeared in the next four years. According to the classification systems of the defects and pathologies usually observed in the natural stones [15], these defects could be classified as:

- Group 1-Loss of stone material:

- Back weathering due to loss of crumbs/splinters, Figure 5;

- Back weathering due to loss of undefinable stone aggregates/pieces, Figure 6;

$\bigcirc \quad$ Rounding/notching, Figure 6;

$\bigcirc \quad$ Weathering out of stone components, Figure 7;

$0 \quad$ Break out, Figure 8.

- Group 2-Coloration/Deposits

$0 \quad$ Efflorescence, Figures 7 and 10;

$\bigcirc \quad$ Coloration, Figure 9.

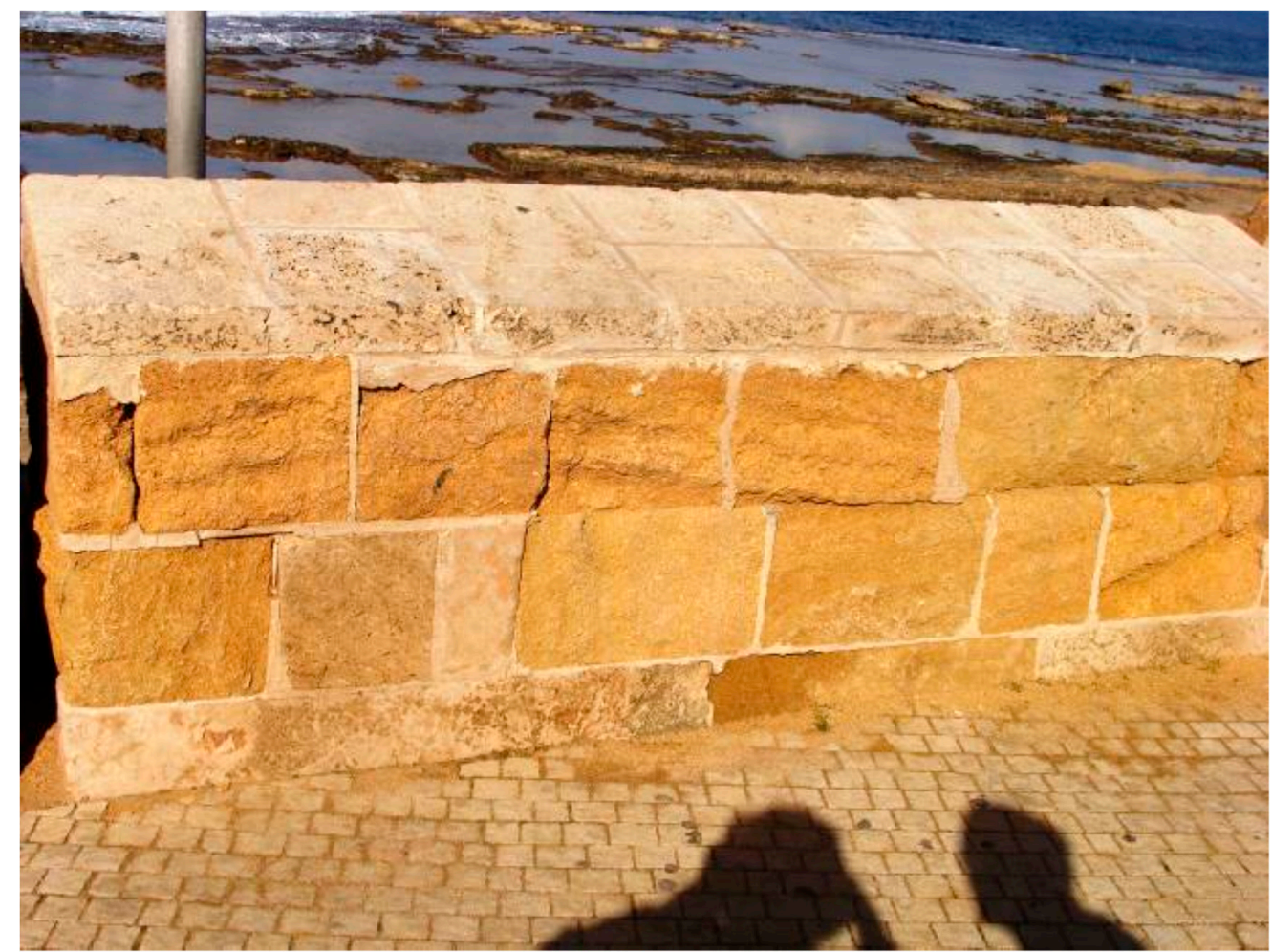

Figure 5. Back weathering of kurkar siding in the Panorama sea walls. Captured by the author on 22 July 2018. 


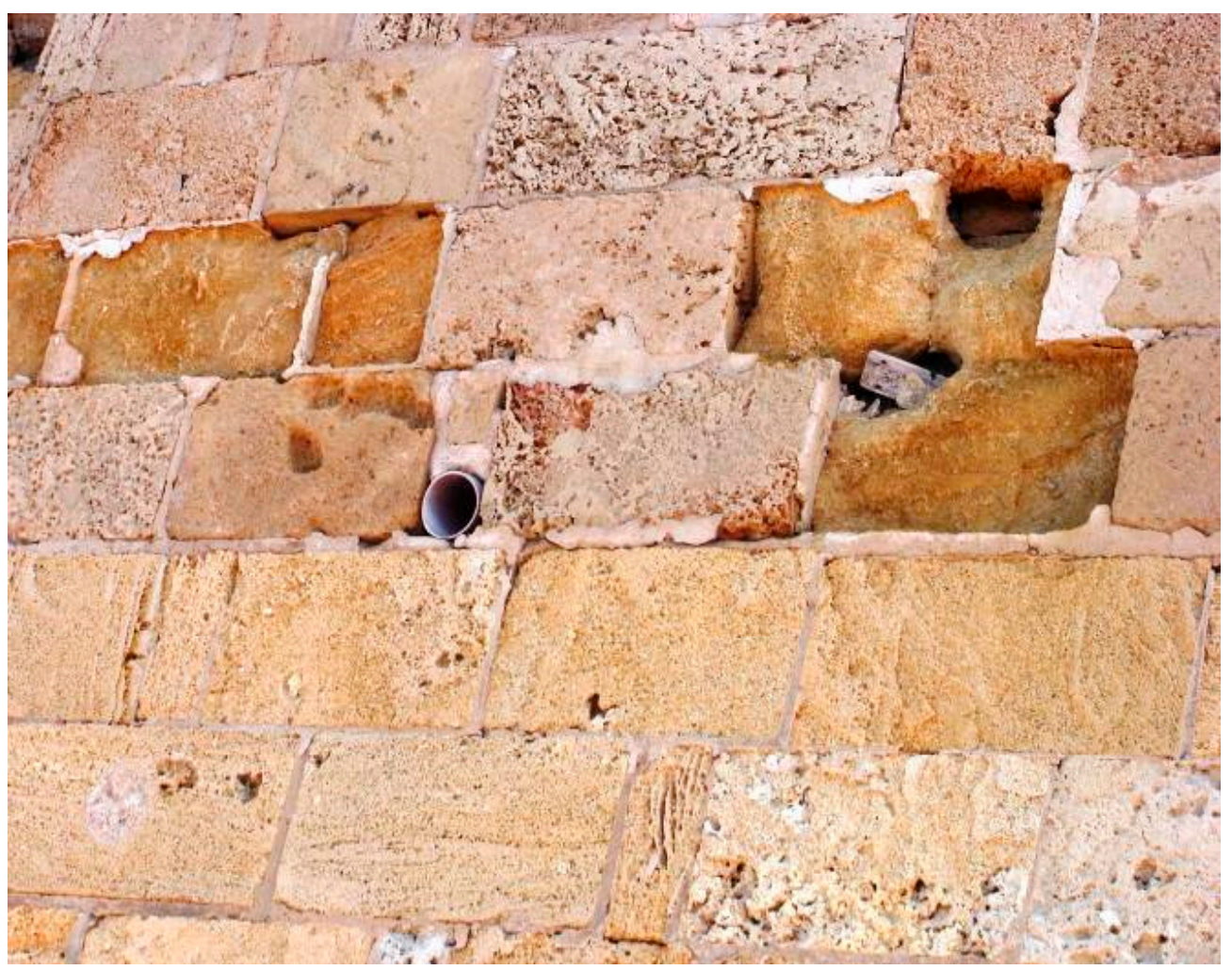

Figure 6. Back weathering of kurkar siding in the Panorama sea walls. Captured by the author on 27 November 2018.

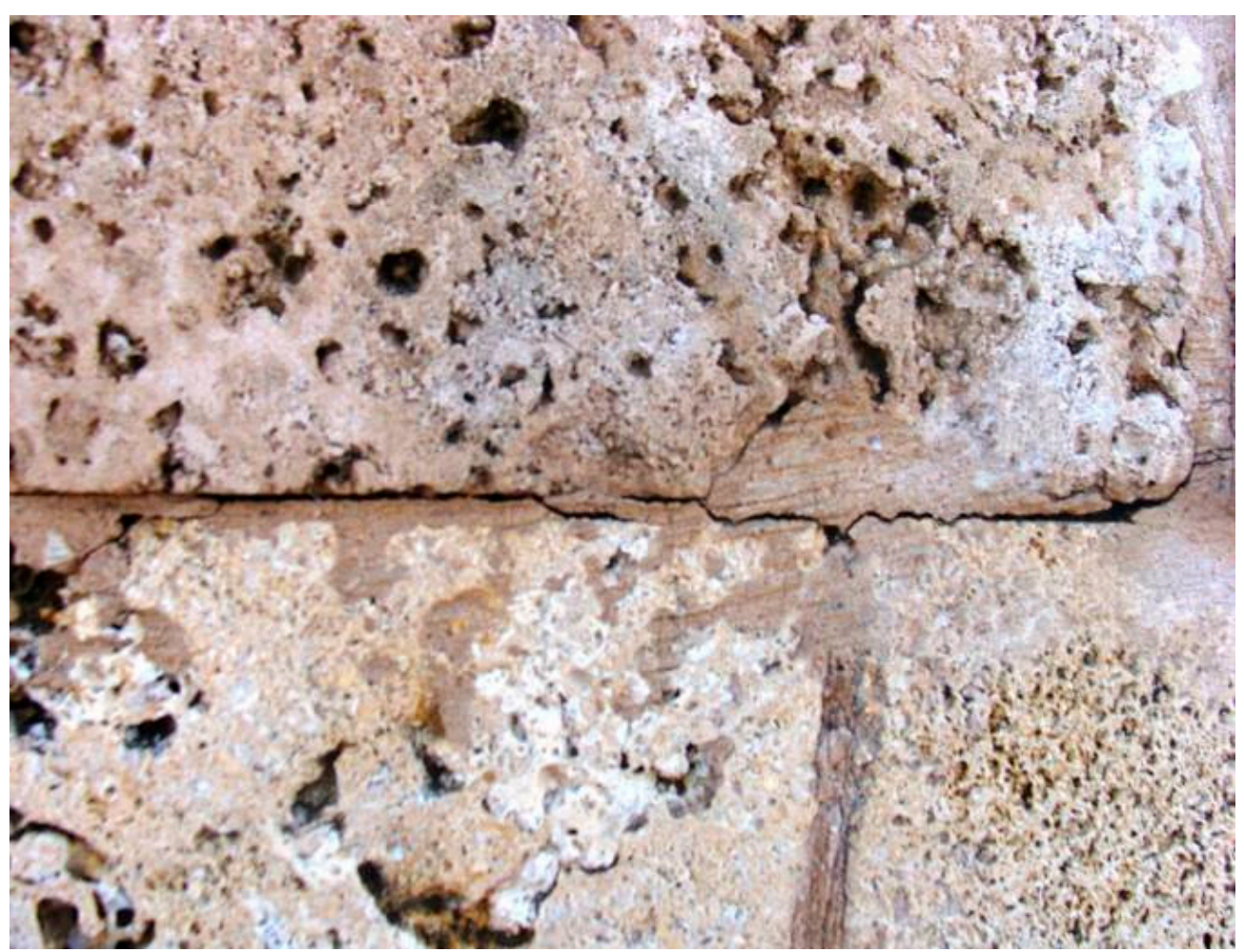

Figure 7. Weathering out of stone components in the Panorama sea walls. Captured by the author on 27 November 2018. 


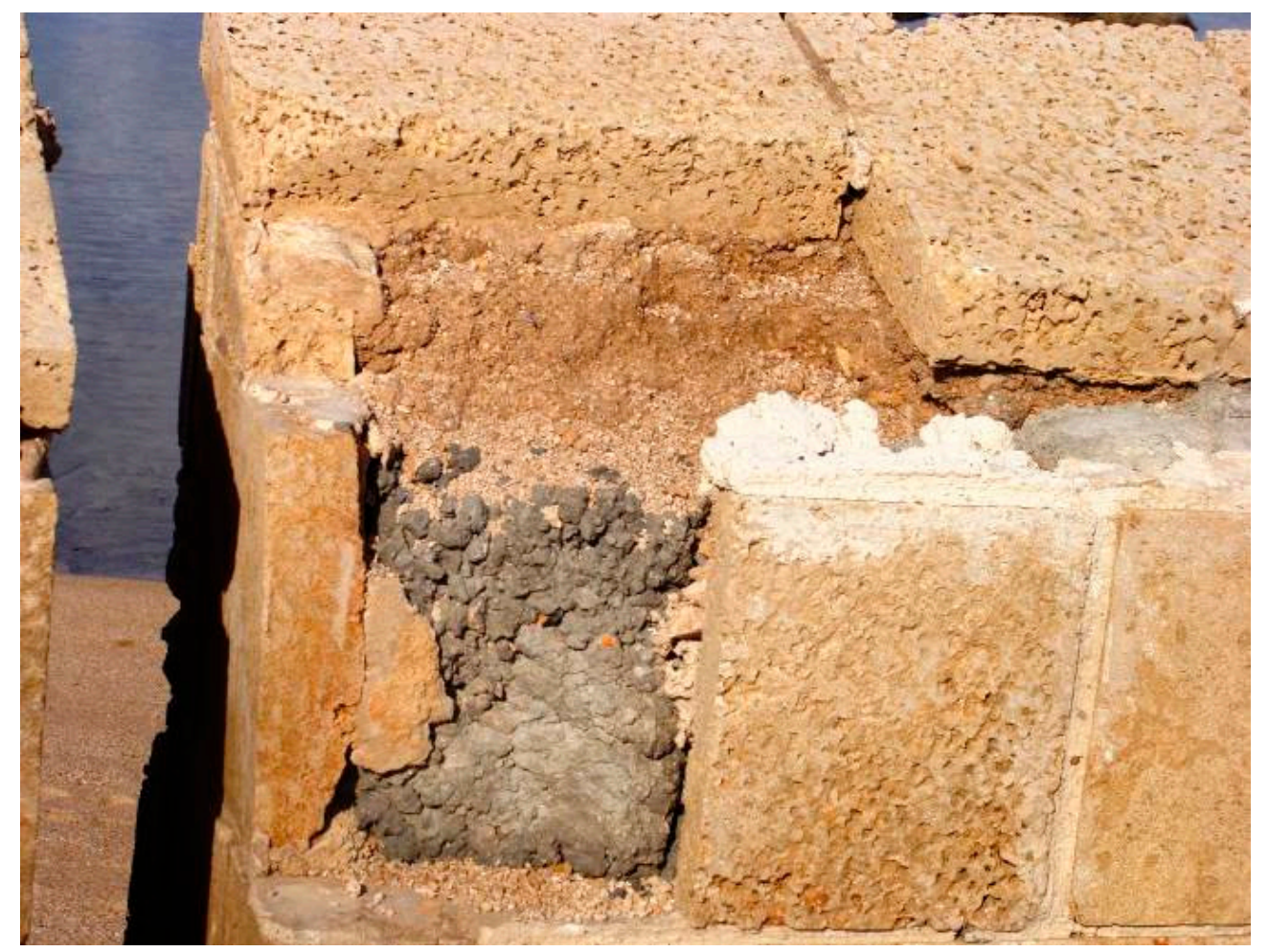

Figure 8. Break out of kurkar stone in the Panorama sea walls. Captured by the author on 27 November 2018.

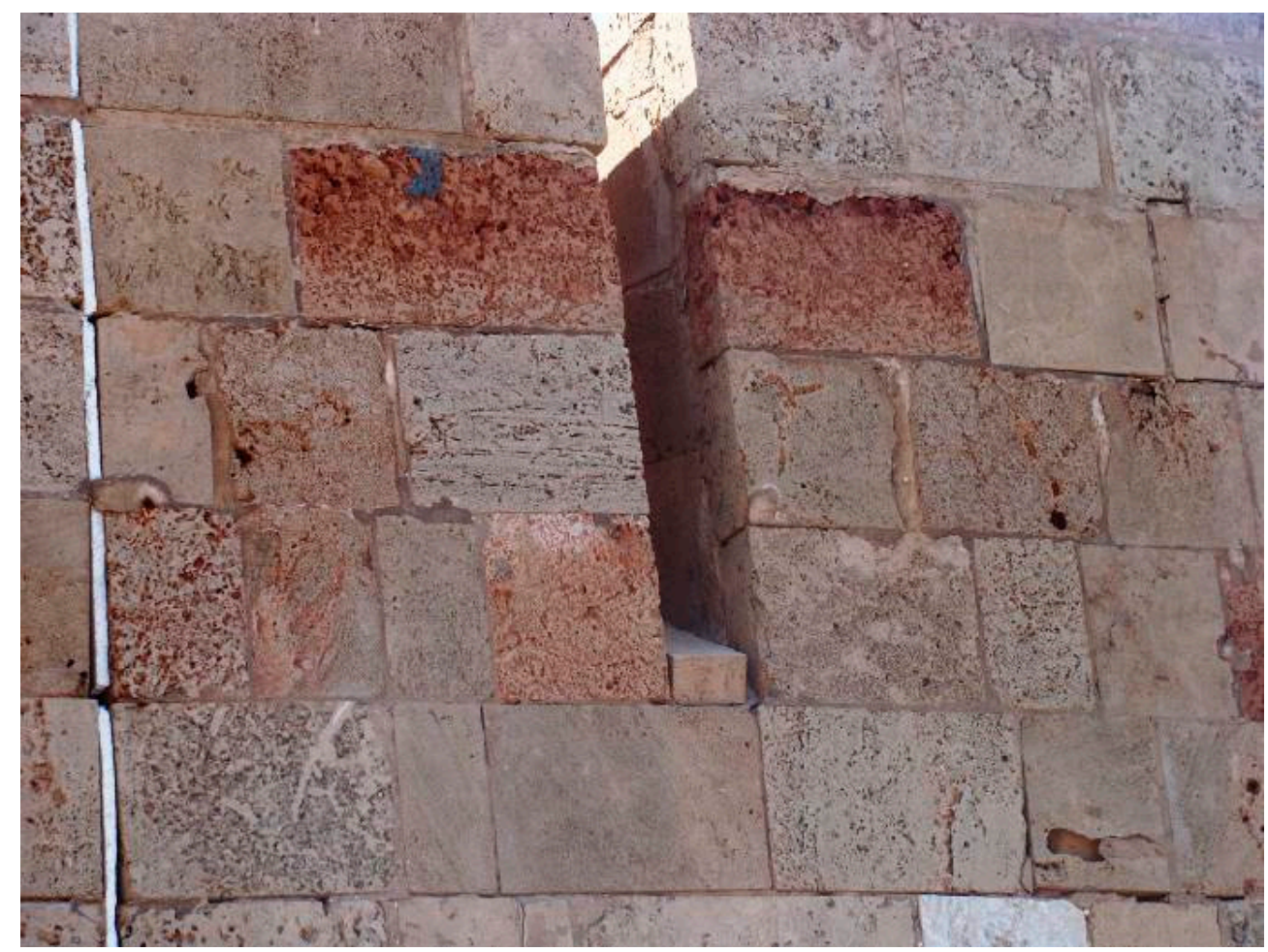

Figure 9. The coloration of kurkar siding in the Panorama sea walls. Captured by the author on 27 November 2018. 


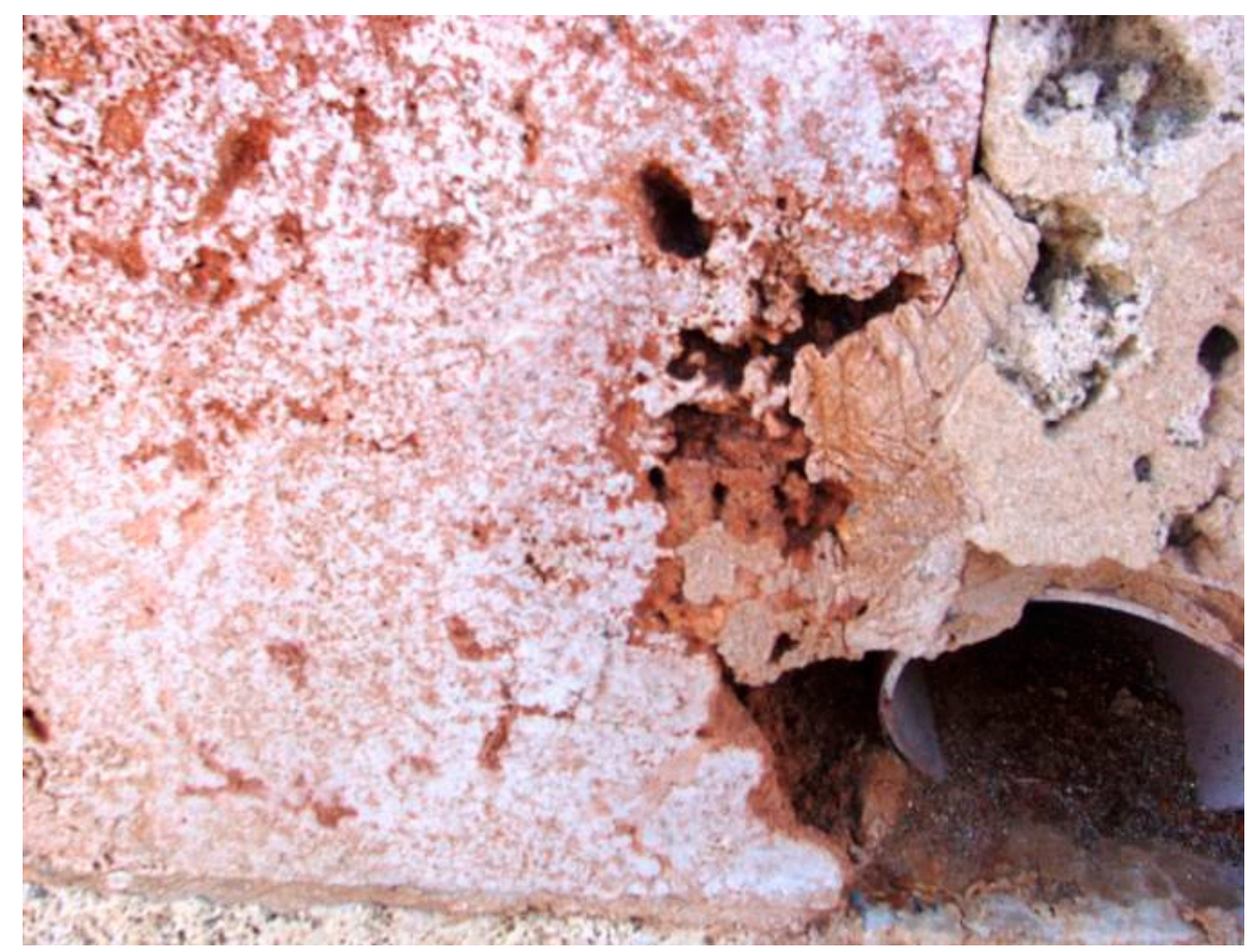

Figure 10. An efflorescence of kurkar siding in the Panorama sea walls. Captured by the author on 27 November 2018.

Except for stones' coloration, these defects have not been observed anytime in the historic sea walls built with the dimensional kurkar stone. Thus, a comprehensive study of the new stone siding has been carried out to reveal the reasons for its deterioration in the contemporary Panorama Sea Walls.

\section{Experimental and Results}

It has always been known that stone quality is the main parameter affecting buildings and constructions' long-term sustainability. Taking into account the fact that the pathological defects have appeared in the Panorama Sea Wall ("exposed in an open place") only a few years after the erection of the wall, one could assume that the qualitative method of assessment proposed by Vitruvius (Vitruvius [16] wrote 2000 years ago: “ . . All these soft kinds have the advantage of being easily worked as soon as they have been quarried. Undercover, they play their part well; but in open and exposed situations, the frost and rime make them crumble, and they go to pieces. On the seacoast, too, the salt eats away and dissolves them, nor can they stand great heat either. But travertine and all stone of that class can stand injury whether from a heavy load laid upon it or from the weather; exposure to fire, however, it cannot bear, but splits and cracks to pieces at once [ ... ] Let the stone be taken from the quarry two years before building is to begin, and not in winter but in summer. Then let it lie exposed in an open place. Such stone as has been damaged by the two years of exposure should be used in the foundations. The rest, which remains unhurt, has passed the test of nature and will endure in those parts of the building which are above ground. This precaution should be observed, not only with dimension stone but also with the rubble which is to be used in walls.") This suggestion proposed two thousand years ago looks to be an entirely true one. However, there is no chance that anybody involved in the tight timetables of the modern construction process will implement this method of natural two-year-long aging to evaluate the durability of the natural stones and reveal their compatibility with the specific service conditions. Currently, there is not any necessity to wait for such a long period (two years) to assess the stone's quality. A combination 
of the modern comprehensive macro-and microstructural analyses with the accelerated weathering tests could provide an architect, a civil engineer, and a contractor with essential information on the stone's durability. Unfortunately, the contractor carried very scarce tests before the construction of the Panorama Sea Wall. Thus, the current investigation was carried out to answer two main questions:

- Was it realistic to predict kurkar stone durability trends before its implementation in the Panorama Sea Wall?

- What factors have led to the quick deterioration of kurkar stone siding in the contemporary Panorama Sea Wall, although the kurkar stones in Acre's historic sea wall were less deteriorated?

\subsection{Mineral Composition}

X-ray diffraction, XRD, was used to determine the majority and minority (with content up to $1-2 \%$ (weight percent).) minerals in the kurkar stone, see Figure 11.

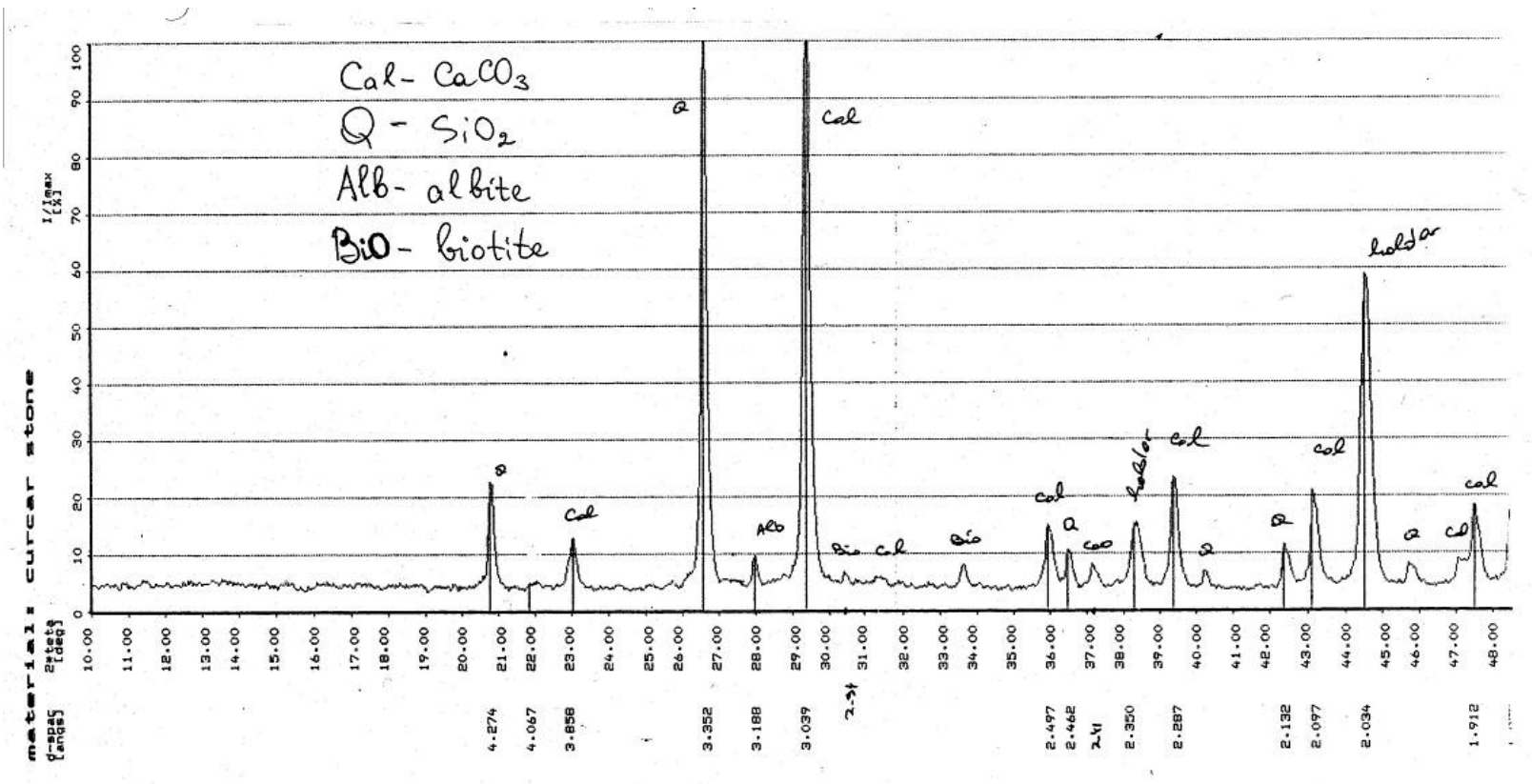

Figure 11. XRD diffraction of kurkar sandstone.

The main minerals determined were calcite, $\mathrm{CaCO}_{3}$, and quartz, $\mathrm{SiO}_{2}$. The secondary minerals found in the kurkar sandstone were albite, $\mathrm{NaAlSi}_{3} \mathrm{O}_{8}$, and biotite $\mathrm{K}(\mathrm{Fe}$, $\mathrm{Mg})_{3} \mathrm{AlSi}_{3} \mathrm{O}_{10}$.

Petrographic analysis of the kurkar stone was performed in a thin section by polarized light microscope Olympus-2. The petrographic thin sections were prepared after impregnation with polystyrene resin under vacuum, then slicing and polishing a slide to $0.03 \mathrm{~mm}$ thickness. The film sections were also stained with Alizarin Red to differentiate calcite from dolomite. The petrographic descriptions were done according to [17,18].

The investigated kurkar stone consists of well-sorted subangular to subrounded quartz, minor amounts of feldspar, heavy minerals, and allochems, all ca. $0.2 \mathrm{~mm}$ in size and constituting no less than $50 \%$ of the texture, Figure 12a. Sand grains are firmly cemented by micro-sparitic to dominantly micritic calcite of the different grain-size with minor porosity. Figure 12 shows the contact between the micritic cement (upper part of the picture) and the microsparitic, coarser calcite cement (lower part of the photo). Calcitic cement of kurkar is very heterogeneous, Figure 12a. Most pores are in micritic cement, Figure 12b. There were observed signs of recrystallization of calcite in the pores, Figure 12b. 


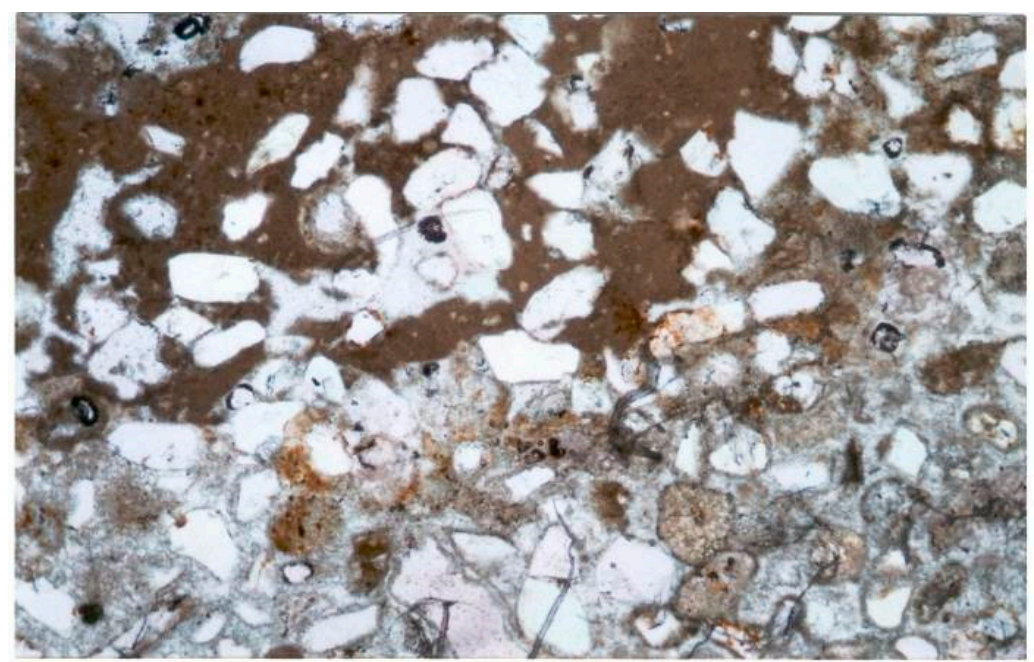

(a)

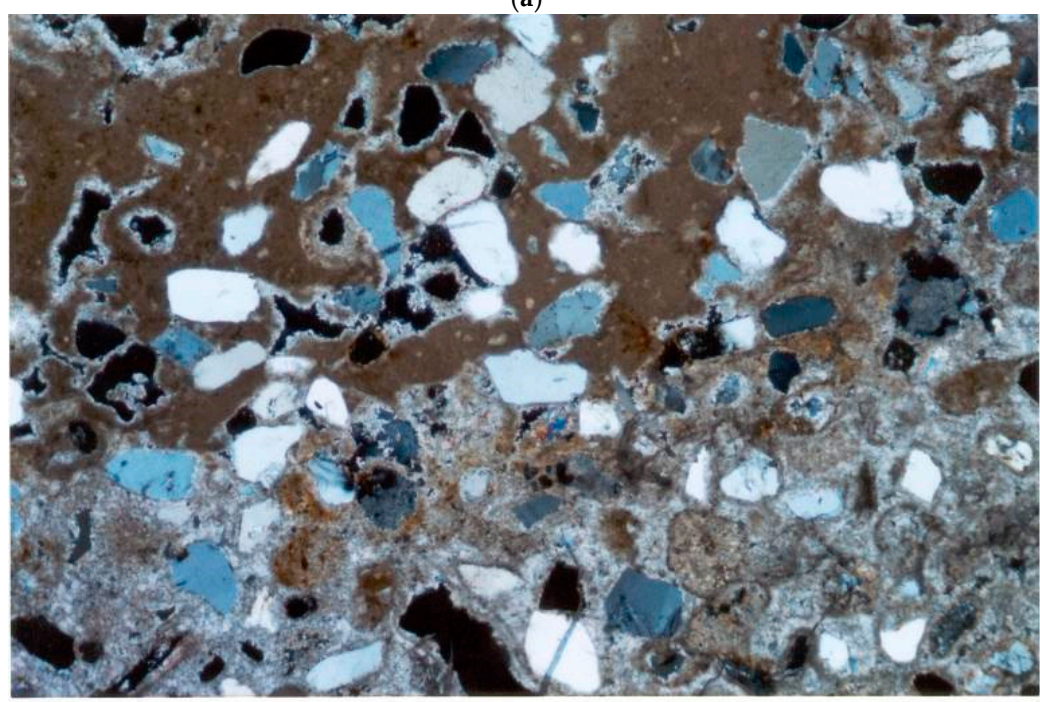

(b)

Figure 12. Kurkar stone upon the petrographic investigation. The black areas are pores: (a) Plain light; (b) Polarized light.

\subsection{Physical Properties and Strength}

The comprehensive study of the physical properties of unweathered (new) kurkar stones and weathered stones drilled off the Panorama Sea Walls was carried out to reveal kurkar deterioration trends. Considering the anisotropy of kurkar sandstone [1], the physical properties and strength of kurkar stone were tested in two directions: parallel to rift and perpendicular to it. (The rift is the plane along which the stone cleaves with the greatest ease [19]. The rift is due to parallel cracks in the quartz of the rocks. The rift plane's effect on the physical and mechanical properties of the natural stone was discussed in detail elsewhere $[20,21]$.) Saturation (Hirschwald's) coefficient was calculated as a ratio of capillary and total porosities [22]. Hirshcwald's coefficient has been widely used for estimating the stones' softening trends since 1911 [22]. The Hirschwald's coefficient is the saturation ratio of the sample obtained from the 24 hours' porosity test. It quantifies the proportion of the porous network that is freely accessible to water under natural absorption conditions. This coefficient was found to be a beneficial one for assessing the trends of building stones' durability $[3,19-23]$. The saturation ratio $(\leq 1)$ is linked to the porous structure's connectivity: a high saturation coefficient often means high connectivity [24]. Stones with high saturation coefficient are substantially more susceptible to weathering, especially to frost weathering $[3,19]$ : 
- $\quad \mathrm{S}>0.85$-susceptible.

- $\quad 0.75<\mathrm{S}<0.80$-moderate resistant.

- $\mathrm{S}<0.75$-frost resistant.

Generally, the frost climate conditions are a sporadic event in Acre Bay. However, Hirshcwald's coefficient is a more straightforward, smarter, and faster way to estimate weathering trends of stones subjected to the salt crystallization. As the results published elsewhere have revealed, this approach is possible: the life cycle of sandstones subjected to the salt crystallization might be at least twice shorter than during their exposure to frost weathering [25]. One of the most critical issues affecting sandstones' resistance to salt weathering is the drying rate function, i.e., the sandstones characterized by a relatively slow drying rate show very intensive scaling damage [26].

The test of water evaporation capacity was carried out for both unweathered and weathered kurkar stones according to the procedure described in [24]. The ratio between amounts of evaporated water and water absorbed in 7 days was calculated.

The results of the tests are summarized in Table 2.

Table 2. Properties of weathered versus unweathered kurkar stones.

\begin{tabular}{|c|c|c|c|c|c|c|c|c|}
\hline \multirow[b]{2}{*}{ Property } & \multicolumn{4}{|c|}{ Unweathered Stone } & \multicolumn{4}{|c|}{ Weathered Stone (Cored from the Wall) } \\
\hline & $\begin{array}{l}\text { Minimal } \\
\text { Value }\end{array}$ & $\begin{array}{l}\text { Maximal } \\
\text { Value }\end{array}$ & Average & $\begin{array}{l}\text { Standard } \\
\text { Deviation }\end{array}$ & $\begin{array}{l}\text { Minimal } \\
\text { Value }\end{array}$ & $\begin{array}{l}\text { Maximal } \\
\text { Value }\end{array}$ & Average & $\begin{array}{l}\text { Standard } \\
\text { Deviation }\end{array}$ \\
\hline $\begin{array}{l}\text { 'Capillary absorption coefficient, } \\
\text { g per } \mathrm{m}^{2} \text { per hour } \frac{1}{2}\end{array}$ & & & & & 1747 & 25,398 & 13,569 & 8924 \\
\hline - $\quad$ parallel to rift plane & 1601 & 1907 & 1777 & 158 & & & & \\
\hline - $\quad$ perpendicular to rift plane & 2073 & 3176 & 2765 & 603 & & & & \\
\hline $\begin{array}{l}\text { Total water absorption, } \mathrm{W} \text {, mass } \\
\%\end{array}$ & 3.3 & 10.4 & 4.8 & $\mathrm{n} / \mathrm{a}$ & 3.7 & 13.0 & 7.3 & $\mathrm{n} / \mathrm{a}$ \\
\hline $\begin{array}{l}\text { Saturation (Hirschwald's) } \\
\text { coefficient [22] }\end{array}$ & & & & & 0.76 & 0.80 & 0.78 & $\mathrm{n} / \mathrm{a}$ \\
\hline - $\quad$ parallel to rift plane & 0.3 & 0.5 & 0.35 & $\mathrm{n} / \mathrm{a}$ & & & & \\
\hline - $\quad$ perpendicular to rift plane & 0.4 & 0.6 & 0.52 & $\mathrm{n} / \mathrm{a}$ & & & & \\
\hline \multicolumn{9}{|l|}{$\begin{array}{l}\text { Water evaporation capacity, w. \%, } \\
\text { after }\end{array}$} \\
\hline$-\quad 24 \mathrm{~h}$ & & & $68 \%$ & & & & $30 \%$ & \\
\hline$-\quad 96 \mathrm{~h} ;$ & & & $90 \%$ & & & & $83 \%$ & \\
\hline $168 \mathrm{~h}$ & $\mathrm{n} / \mathrm{a}$ & $\mathrm{n} / \mathrm{a}$ & $100 \%$ & $\mathrm{n} / \mathrm{a}$ & $\mathrm{n} / \mathrm{a}$ & $\mathrm{n} / \mathrm{a}$ & $91 \%$ & $\mathrm{n} / \mathrm{a}$ \\
\hline \multicolumn{9}{|l|}{ Compressive strength, $\mathrm{MPa}$} \\
\hline - $\quad$ load parallel to rift plane & 6.3 & 34.4 & 14.0 & 8.8 & 6.8 & 25.6 & 11.7 & 8.6 \\
\hline $\begin{array}{l}\text { - load perpendicular to rift } \\
\text { plane }\end{array}$ & 3.7 & 12.5 & 6.6 & 3.0 & 2.1 & 10.1 & 5.1 & 2.2 \\
\hline \multicolumn{9}{|l|}{ Modulus of rupture, $\mathrm{MPa}$} \\
\hline - $\quad$ parallel to rift plane & 4.2 & 8.8 & 6.2 & 1.7 & 2.8 & 4.0 & 4.0 & 1.4 \\
\hline - $\quad$ perpendicular to rift plane & 3.3 & 6.0 & 4.9 & 1.1 & $\mathrm{n} / \mathrm{a}$ & $\mathrm{n} / \mathrm{a}$ & $\mathrm{n} / \mathrm{a}$ & $\mathrm{n} / \mathrm{a}$ \\
\hline
\end{tabular}

The results presented in Table 2 have revealed the severe deterioration of kurkar sandstone caused by stone weathering in exposure to the hazardous offshore conditions. In comparison to unweathered kurkar stone, the weathered samples were characterized by the following properties: 
- The decreased compressive strength and modulus of rupture, i.e., a drop of 16 to $23 \%$ and 18 to $35 \%$, respectively.

- The capillary absorption rise: 4.9 to 7.6 times as much as of the original unweathered stone.

- The total absorption has dramatically risen due to weathering, and it was 1.5 times more than in the original unweathered stone.

- A sharp decline of the initial evaporation capacity was observed: about twice as less as in the unweathered stone.

- An increase in the saturation (Hirschwald's) coefficient of weathered stones is more than twice as high as observed in the unweathered samples.

\subsection{Soundness}

Figure 13 presents the original curkar sandstone pictures and the weathered one after their exposure to the accelerated weathering test. The soundness of kurkar was estimated by evaluating the changes in the capillary absorption, modulus of rupture, and loss of weight after the laboratory exposure of unweathered kurkar stone to 15 accelerated weathering cycles consisted of submersion of kurkar sandstone in sodium sulfate solution (concentration of $14 \mathrm{w}$. \%) for $24 \mathrm{~h}$ and its oven-drying at $103 \pm 2{ }^{\circ} \mathrm{C}$ for $24 \mathrm{~h}$ afterward [27].

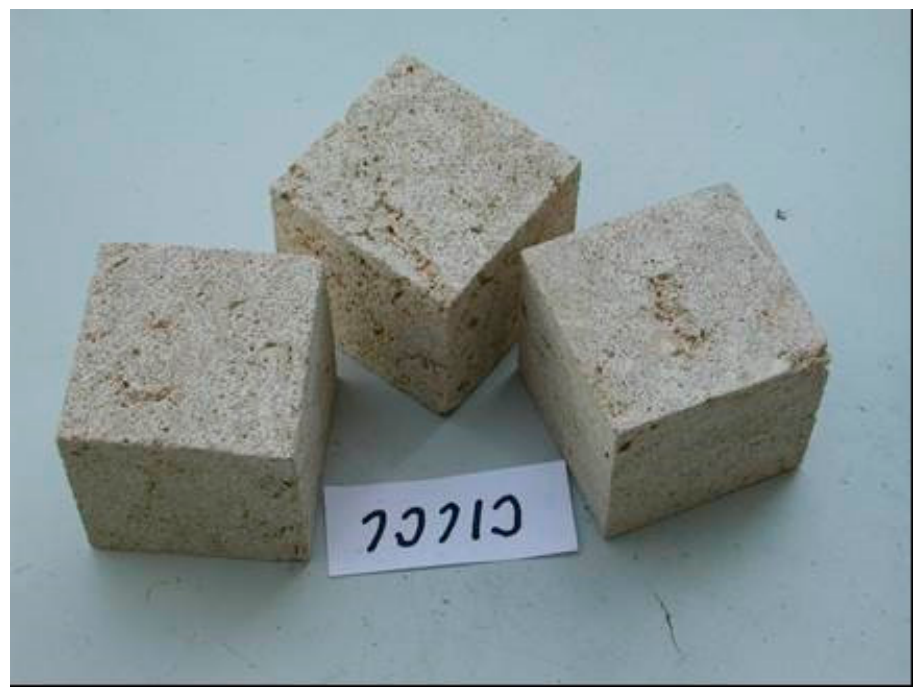

(a)

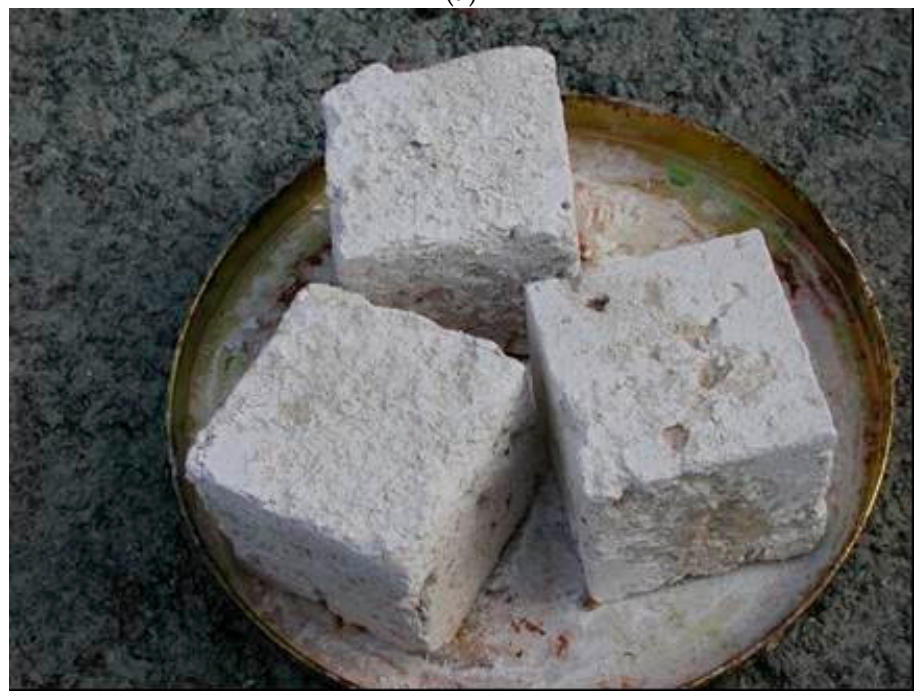

(b)

Figure 13. Kurkar sandstone before and after accelerated weathering test in a sodium sulfate solution. (a) Unweathered stone samples. (b) Stone samples after accelerated weathering test. 
The average capillary absorption coefficient of kurkar sandstone after its exposure to the soundness test was as follows:

- Perpendicular to rift plane-from 3291 to 4956 g per $\mathrm{m}^{2}$ per $\mathrm{h}^{\frac{1}{2}}$ or 2.9 to $4.4 \%$ (w. \%). - $\quad$ Parallel to rift plane-from 3989 to $4227 \mathrm{~g}$ per $\mathrm{m}^{2}$ per $\mathrm{h}^{\frac{1}{2}}$ or 3.5 to $3.8 \%$ (w. \%).

After the accelerated weathering test, the modulus of rupture measured perpendicular to the rift plane was 2.8 to $4.0 \mathrm{MPa}$. Thus, a drop of $30 \%$ in the modulus of rupture should be considered. After accelerated weathering cycles, a loss of kurkar sandstone weight was 0.6 to $1.7 \%$ (w. \%).

\section{Discussion}

As was stated previously, drawing on the statements presented in [1] and basing on the results in Table 2, the original kurkar sandstone could be considered as a strongly anisotropic material. Generally, anisotropy is defined as a directional dependency of stone properties that determines the quality and resistance of stone against decay caused by harmful agents, such as water, salts, and air pollution [2,3,25]. Furthermore, kurkar sandstone's heterogeneous mineralogical composition hints at the possible deterioration when the stone is exposed to a hazardous environment. Micritic calcite (see Figure 11) has a poorly washed sandstone texture with a clay-enriched matrix that has not been leached yet $[16,17]$.

Calcite, $\mathrm{CaCO}_{3}$, is one of two main minerals of kurkar sandstone. Weathering of calcite in the offshore zone might dissolve its calcium ions and form gypsum crust at the stone surface.

The breeze shoves salty seawater into the stone. This salted water is intensively absorbed by porous kurkar because of capillary forces. Therefore, the pore solution becomes gradually supersaturated. Thus, the salts like halite, $\mathrm{NaCl}$, sanderite, $\mathrm{MgSO}_{4} \cdot 2 \mathrm{H}_{2} \mathrm{O}$, epsomite, $\mathrm{MgSO}_{4} \cdot 7 \mathrm{H}_{2} \mathrm{O}$, thenardite, $\mathrm{Na}_{2} \mathrm{SO}_{4}$, mirabilite, $\mathrm{Na}_{2} \mathrm{SO}_{4} \cdot 10 \mathrm{H}_{2} \mathrm{O}$ and gypsum, $\mathrm{CaSO}_{4} \cdot 2 \mathrm{H}_{2} \mathrm{O}$ might crystalize from the supersaturated pore solutions. Their crystallization is followed by the very high crystallization pressure ( 100 MPa) destroying stone [28]. Accelerated weathering test of kurkar stone in sodium sulfate solution, see Figure 13, has shown that kurkar sandstone is prone to destructive pressure during salt crystallization. The physical and mechanical properties of kurkar sandstone have been worsened after natural weathering in the Panorama Sea Wall, see Table 2, and after the accelerated weathering test, as well. Both weathering processes, the environmental one and the accelerated one, have caused a loss of stone material and led to the efflorescence process. The tests carried out in the current study have reaffirmed the standard accelerated-weathering test [27] in predicting stone durability's trends. Thus, an accelerated weathering test before setting the stone in outside veneers might help ensure their quality. Unfortunately, this test was disregarded entirely during the construction of the Panorama Sea Walls.

The petrographic analysis, Figure 12, has revealed the substantial amounts of feldspar minerals in kurkar sandstone. XRD analyses have explained that the type of feldspar in kurkar sandstone is albite. Biotite (sodium aluminum silicate) found in kurkar sandstone is a phyllosilicate mineral in the common mica group. Unfortunately, the years 1995-2015 were characterized by extremely high levels of air pollution $\left(\mathrm{NO}_{\mathrm{x}}, \mathrm{SO}_{2}\right.$, and $\left.\mathrm{CO}_{2}\right)$ in Haifa and Acre Bays adjacent to the big industrial zone and the high traffic areas (The historical data on the levels of air pollution could be found in the database of Israeli Ministry of Environmental Protection (https://www.gov.il/en/departments/topics/reducing_air_ pollution). Following a 2015 government decision, implementing the 2015-2020 National Plan to Reduce Air Pollution in Haifa and Acre Bays began in 2016. The National Plan, which has a budget of NIS 115.5 million, is expected to reduce industrial air pollution in the Haifa Bay vicinity, incl. Acre Bay by 50\% [29-31]. According to the NUMBEO database, the air pollution index in Acre, Israel is ca. 75, which is high [31]). Weathering of albite feldspar and biotite mica under these conditions might cause their chemical alteration and decomposition under the following scenario: 
(a) Sulphuric and nitric acids, which are supplied by acid precipitation because of air pollution, take over from carbonic acid in weathering reactions of albite, which induced a decrease in the atmospheric/soil $\mathrm{CO}_{2}$ consumption by weathering [32]. The high air pollution in the urban environment causes dissolving $\mathrm{CO}_{2}$ in water and carbonic acid formation afterward. This process promotes the mineral weathering of albite feldspar in kurkar sandstone and results in albite kaolinization [32-34]:

$$
\text { Albite }+5.5 \mathrm{H}_{2} \mathrm{O}+\mathrm{CO}_{2}=\mathrm{HCO}_{3}{ }^{-}+\mathrm{Na}^{+}+2 \mathrm{H}_{4} \mathrm{SiO}_{4}+0.5 \mathrm{Kaolinite}
$$

Generally, kaolinization is a long-term process. However, this process is strongly enhanced by the hot, humid climate and acidic $\mathrm{pH}$, and its time is reduced dramatically [35]. Biotite is also a mineral of a highly sensitive nature, and it has a strong tendency to kaolinization when exposed to elevated temperatures and a non-neutral acidic $\mathrm{pH}$ [36]. Furthermore, it is might also be partially degraded upon low and high alkali $\mathrm{pH}$ values [32-34]

(b) Kurkar sandstones in the Panorama Sea Walls have always been exposed to the non-stop dry-wet cycles in acidic and alkaline environments with high levels of air pollution (acidic pH ca. 4.0 (estimated) and seawater breeze (alkaline $\mathrm{pH}$ ca. 8.5-9.0), respectively. The dissolution reactions of albite and calcite minerals that form cement in sandstone are too spontaneous in an acidic environment. In an alkaline solution, the dissolution reaction of quartz in sandstone is spontaneous $[25,28]$. The dissolution of the large amounts of sandstone cement explains kurkar crumbling (see Figure 5) and a sharp decrease in the mechanical properties of naturally weathered kurkar (see Table 2). A sharp rise in capillary absorption could be partially attributed to quartz (aggregate) dissolution leading to the high sandstone porosity, see Figure 7. A dissolution of silicon and a release of iron (II) ions from biotite subjected to the solutions with the low and near neutral (alkali) $\mathrm{pH}$ is found to occur within the first ten months of exposure [32,34]. The oxidation of iron (II) to iron (III) in Panorama Sea Walls' sandstone might be a rapid process given the seawater chlorides absorbed by kurkar. Furthermore, the rusty coloration of kurkar, see Figure 9, has resulted from these redox reactions of iron phases released by biotite because of its degradation.

(c) The walls were cast in-situ against sandstone veneer siding. Thus, one can conclude with confidence that kurkar stone has been, for at least 28 days, in direct contact with fresh and hardening cement-based matrix, which means that kurkar absorbed high $\mathrm{pH}$ alkali solutions from concrete. It is common knowledge that the $\mathrm{pH}$ of fresh and hardening concrete is ca.12 to 13 , and alkalis in it are $\mathrm{Ca}^{2+}$ (major alkali) and $\mathrm{Na}^{+} \& \mathrm{~K}^{+}$(minor alkalis).). Furthermore, salt-containing seawater breeze and acid air pollution in Acre Bay have promoted the formation of significant efflorescence at kurkar face surface, see Figures 7 and 10 (The chemical composition of such efflorescence might be variable and consists of the following salts: halite, $\mathrm{NaCl}$, thenardite, $\mathrm{Na}_{2} \mathrm{SO} 4$, mirabilite, $\mathrm{Na}_{2} \mathrm{SO}_{4} \cdot 10 \mathrm{H}_{2} \mathrm{O}$, thermonatrite, $\mathrm{Na}_{2} \mathrm{CO}_{3} \cdot \mathrm{H}_{2} \mathrm{O}$, gypsum anhydrite, $\mathrm{CaSO}_{4}$ and gypsum, $\mathrm{CaSO}_{4} \cdot 2 \mathrm{H}_{2} \mathrm{O}$, depending on (a) seawater moisture content in kurkar sandstone, (b) concentration of alkalis absorbed by sandstone from fresh and hardening mortar/concrete and (c) levels of the local air pollutions [28-42].

Those mentioned above physical and chemical processes caused a loss of kurkar components, see Figure 7; breaking out the stone matter, see Figure 8, and the rusty coloration of kurkar, see Figure 9.

The study of the mineralogical composition by petrographic analysis and XRD test has shown that the secondary minerals in kurkar sandstone have been responsible for some weathering processes in the Panorama Sea Wall. The study of the mineralogical composition of stone before beginning the construction process is a well-known and reliable method to reveal the likely trends of stone weathering over the lifetime of stone covering. Unfortunately, this analysis has not been mandatory in Israel in the relevant period. Therefore, it was completely disregarded during the construction of the Panorama Sea Walls. 
The physical and mechanical properties of kurkar sandstone have been sufficiently altered and worsened even after a concise service life of the Panorama Sea Walls (see Table 2):

- Water absorption and Hirshwald's coefficient have been substantially increased;

- Water evaporation and mechanical strength have been considerably decreased.

Generally, the high water absorption of natural stone together with its prolonged moisture evaporation (i.e., lousy breathability), and the unstable mineralogical composition are the well-known warning signs of probably rapid decay of external stone cladding in the course of exposure to severe hazardous environmental conditions, as explained in Figure 14. This situation was in the case with the Panorama Sea Wall, i.e., increasing the water absorption and worsening the evaporation characteristics of kurkar sandstone in the course of its service life have been a source, an accelerator, and an outcome (a loop process) of physical weathering, chemical alteration decay degradation of wall siding. Furthermore, this process also led to the low strength characteristics of stones (see Table 2).

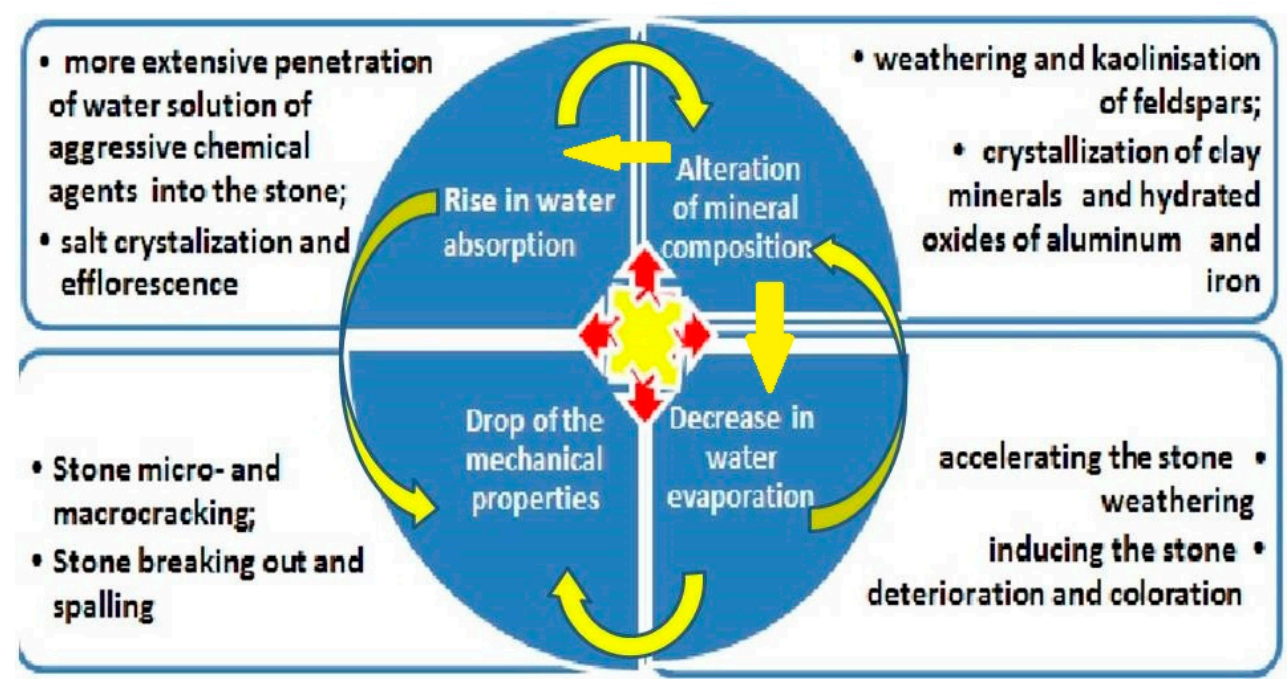

Figure 14. Diagram presenting the Interaction between the changes in the different stone properties.

Impact of Construction Technology on Durability of Kurkar Sandstones in the Historic Sea Walls Versus the Panorama Sea Walls in Acre

The tests of water absorption and mechanical strength of new stones are mandatory in Israel. The total water absorption of stones used in Israeli buildings' external cladding should be less than $2 \%$ (weight \%) [8]. However, the project planners decided at the design phase that kurkar stones in the Panorama Sea Walls need not meet this standard specification requirement. This decision was adopted due to the time-honored successful experience with kurkar masonry in Acre's historic seawalls. Unfortunately, this approach was completely wrong because of the different aging behavior of thick dimensional stones in the landmark sea walls compared to the thin stone cladding in the modern Panorama Sea Walls.

The critical fact is that the historic seawalls in Acre were constructed more than 200 years ago. The historic masonry construction was based on adhering the blocks of dimensional kurkar ashlar stones using air lime mortar. This kurkar stonework was very popular in offshore construction in Israel till the 1950s, and since the 1960s, the dimensional stones have not been used at all in Israeli construction. Generally, because of the replacement of dimensional building stone in masonry with concrete blocks. These thick dimensional stones in the historical sea walls look today less deteriorated than kurkar stone plates used as the modern Panorama Sea Walls' cladding. (The deterioration and structural problems of stonework in the historic sea walls were described and thoroughly analyzed in the conservation project [40]). A primary reason for this discrepancy in weathering 
behavior of kurkar sandstones exposed to the same external environmental conditions are the different construction technologies:

- The ashlar kurkar blocks, ca. 0.3-0.6 m long, thick, and wide by size, were used in the Historic Walls' stonework in Acre. In these Walls, the bed joints were made of air lime mortar, [41], see Figure 15. Air lime mortar covered ca. 15\% of each kurkar block's total surface, and the rest of the body has been left breathable and useful for the evaporation of moisture from the historic sea walls.

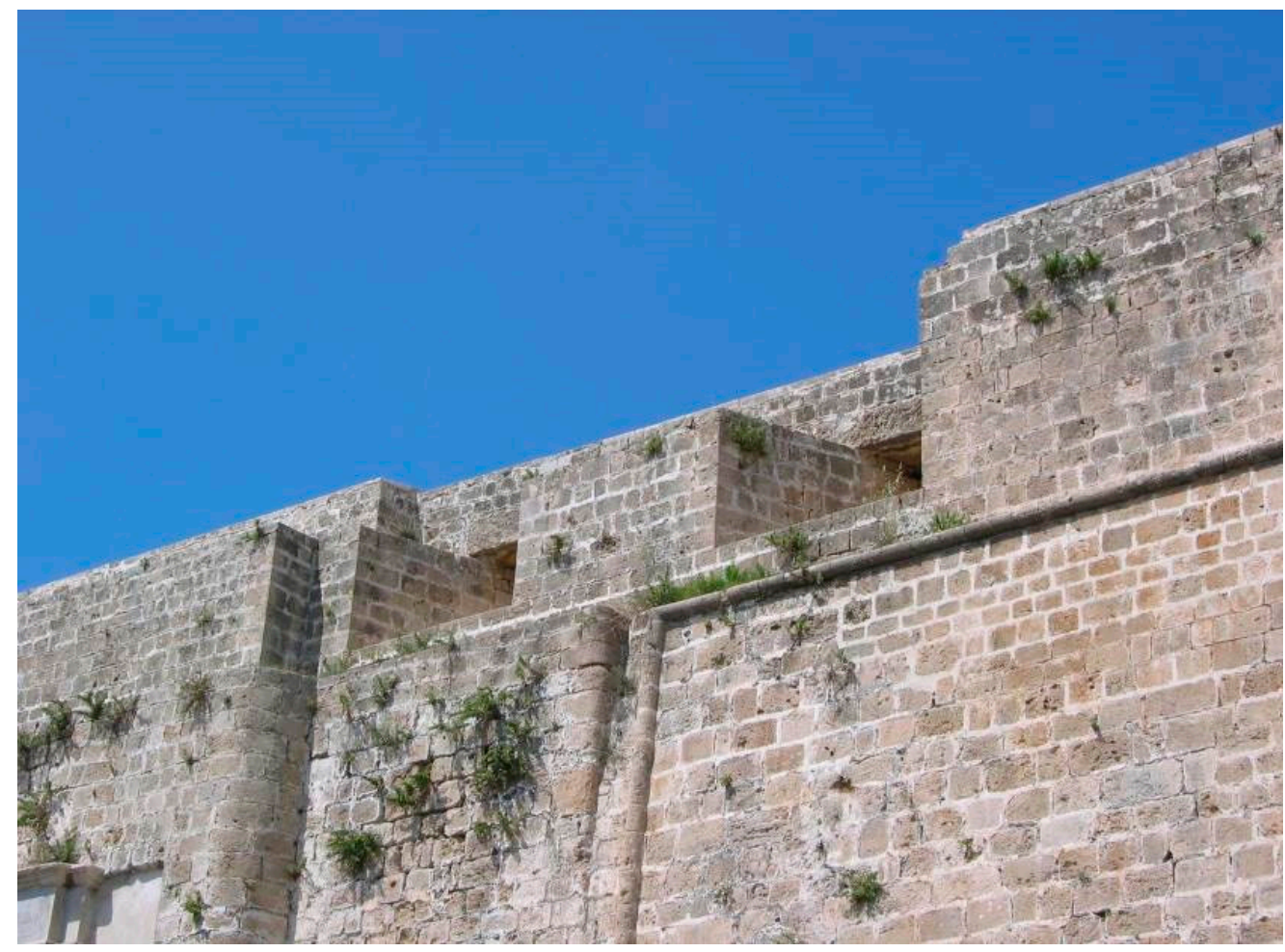

Figure 15. Acre historic wall with the lime-mortar bed joints (source: https:/ / commons.wikimedia. org/wiki/File:Acre_-_wall.JPG. Accessed on 11 November 2020).

The modern Panorama Sea Walls are constituted of the reinforced concrete wall cast against the porous sandstone veneer. This stone veneer has been made of kurkar plates ca. $0.3-0.5 \mathrm{~m}$ long and wide and up to $0.15 \mathrm{~m}$ thick by size, see Figure 4 . The joints between the stones in the veneer and the veneer's background consist of Portland cement mortar and concrete, respectively. Portland cement matrix covered ca. $70 \%$ of the total surface of the kurkar plate, and only $30 \%$ of the surface is useful for the evaporation of moisture from the wall. However, Portland cement mortar is always much denser than air lime mortar, whether its evaporation ability is far less than that of the last one. This fact is the core reason why cement-based mortars are not breathable enough. Thus, the deterioration reactions involving the hazardous environmental agents and moisture absorbed by kurkar stone have spread much quicker and intensively in the modern Panorama Sea Walls than the historic sea walls in Acre. Here, the hazardous environmental agents are the high humidity and salinity common in the Mediterranean offshore zone and the local air pollution. In combination with high water absorption of kurkar sandstone and its unstable mineralogical composition, Portland cement mortars and concrete have quickly caused a severe worsening of the physical and mechanical properties of kurkar sandstone siding in the Panorama Sea Wall (see Table 2) and to the apparent defects, as shown in Figures 5-10.

The contemporary architectural conservation science $\mathrm{ABC}$ strictly prohibits Portland cement mortars in the masonry built of porous sedimentary stones, especially sandstone. The architectural conservation projects carried out since the 1990s have revealed a de- 
structive effect of Portland cement mortars on stonework [42-46]. On the contrary, the modern construction codes and standards have been entirely loyal to the implementation of Portland cement mortars and concretes in stone veneer siding. The Panorama Sea Walls in Acre are the contemporary walls designed to stand in the context of historical legacy. However, as has been previously emphasized, the modern construction technology used in the contemporary sea walls is entirely different from the historical one. Portland cement was used in the Panorama Sea Walls in Acre and air lime in Acre's historic walls. Thus, the accelerated deterioration of kurkar sandstone siding in the Panorama Sea Walls has been sufficiently promoted by Portland cement bed mortars and concrete.

\section{Conclusions}

Generally, when the contemporary structure is designed in the historic legacy context, the architectural and aesthetic forms of the modern and historic structures are guaranteed. However, the contemporary and historic construction technologies could be completely different, as was in the historic sea walls and the modern Panorama Sea Walls in Acre City. Thus, the durability of the similar stones used in the historic and contemporary structures has been entirely different. One should remember that sandstones, along with the air lime mortars, are the traditional masonry materials. The conventional masonry technologies have proved themselves as falling into line with the durability trends of sandstones. However, the same kurkar sandstone has been used in the contemporary sea walls, not in the dimensional thick blocks, but as thin siding plates. Steel anchors and grids have fixed these sandstone plates to the structural concrete background cast against the stone veneer. Portland cement mortars and concretes are widely used in contemporary structures to protect the steel reinforcement and fixing elements from corrosion. However, the expected long-term durability of stone veneers used in modern structures might be substantially diminished because of damages in the porous stones caused by Portland cement mortars and concretes. Natural stone veneers should not be implemented in the contemporary concrete sea walls if a wet fixing method basing on Portland cement mortars and concretes is used.

Funding: This research received no external funding.

Institutional Review Board Statement: Not applicable.

Informed Consent Statement: Not applicable.

Data Availability Statement: Data available in a publicly accessible repository.

Conflicts of Interest: No conflict of interest.

\section{References}

1. Greenstein, J. Ultimate strip loading on anisotropic calcareous sandstone. Rock Mech. Felsmech. Mec. Roches 1975, 7, 73-81. [CrossRef]

2. Fort, R.; Varas, M.J.; de Buergo, M.A.; Martin-Freire, D. Determination of anisotropy to enhance the durability of natural stone. J. Geophys. Eng. 2011, 8, S132-S144. [CrossRef]

3. Kovacs, T. Durability of Crystalline Monumental Stones in Terms of Their Petrophysical Characteristics; Alma Mater StudiorumUniversità di Bologna: Bologna BO, Italy, 2009.

4. Petersen, A. A Gazetteer of Buildings in Muslim Palestine (Part 1); Oxford University Press: Oxford, UK, 2001.

5. 14th century BCE COJS-Center for Online Judaic The Amarna Letters. The Amarna Letters, 14th Century BCE. Available online: http://cojs.org/the_amarna_letters-_14th_century_bce (accessed on 1 December 2020).

6. Aharoni, Y. The Land of the Bible: A Historical Geography; Westminster Press: Philadelphia, PA, USA, 1979.

7. Acco, Ptolemais, Acre. Available online: https://www.bibleplaces.com/acco/ (accessed on 1 December 2020).

8. New Testament, Acts 21:7. Available online: https://biblehub.com/acts/21-7.htm (accessed on 1 December 2020).

9. Michaud, F.; Robson, W. The History of the Crusades, Volume 3. Available online: http://books.google.co.uk/books?id= mAcMAAAAYAAJ\&client=firefox-a\&pg=PA70\# $v=$ onepage\& $q \& \mathrm{f}=$ false (accessed on 1 December 2020).

10. Sivan, D.; Porat, N. Evidence from luminescence for Late Pleistocene formation of calcareous aeolianite (kurkar) and paleosol (hamra) in the Carmel Coast, Israel. Palaeogeogr. Palaeoclimatol. Palaeoecol. 2004, 211, 95-106. [CrossRef] 
11. SI 2378 Part 2. Natural Stone Cladded Wall: Walls Cladded Using the Wet Fixing Method; Israeli Standard Institute: Tel Aviv-Yafo, Israel, 2005; p. 44.

12. ASTM C97/C97M-15. Standard Test Methods for Absorption and Bulk Specific Gravity of Dimension Stone; ASTM Compass: West Conshohocken, PA, USA, 2015.

13. EN 1925. Natural Stone Test Methods—Determination of Water Absorption Coefficient by Capillarity; BSI-British Standards Institution: London, UK, 1999; p. 10.

14. C99/C99M-15. Standard Test Method for Modulus of Rupture of Dimension Stone; ASTM International: West Conshohocken, PA, USA, 2015.

15. Fitzner, B.; Heinrics, K. Photo Atlas of Weathering Forms on Stone Monuments. 2004. Available online: http://www.stone.rwthaachen.de/atlas.htm (accessed on 1 December 2020).

16. Bullock, P.; Fedoroff, N.; Iongerius, A.; Stoops, G.; Tursina, T. Handbook for Soil Thin Section Description; Waine Research Publication: Shropshire, UK, 1985.

17. AAdams, E.; MacKenzie, W.S. A Color Atlas of Carbonate Sediments and Rocks under the Microscope, 1st ed.; Manson Publishing Ltd.: Copenhagen, Denmark, 1998.

18. Hirschwald, J. Systematic research of the stone materials of ancient buildings. 2. The weathering of the Otto Heinrich building in the Heidelberg castle. In Bautechnische Gesteinuntersuchungen; Available online: https:/ /www.worldcat.org/title/bautechnischegesteinsuntersuchungen-mitteilungen-aus-dem-mineralog-geolog-institut-der-kgl-technischen-hochschule-berlin/oclc/8915 72775/editions?referer=di\&editionsView=true (accessed on 1 December 2020).

19. Bourgès, A. Holistic Correlation of Physical and Mechanical Properties of Selected Natural Stones for Assessing Durability and Weathering in the Natural Environment; Ludwigs-Maximilians-Universität München: Munich, Germany, 2006.

20. Robert, R. Analytical Characterization of Porous Geomaterials Reference Assessment in Some Sedimentary Rocks; Humboldt-Universität: Berlin, Germany, 2004.

21. Rousset, B.; Gentile, S.; James, J. Injection Grouts for Molasse Sandstones: Preliminary Assesment; Expert-Center for Conservation of Monuments and Sites of Lausanne: Lausanne, Switzerland; Delft, The Netherlands, 2005; p. 11.

22. Ghobadi, M.H.; Babazadeh, R. Experimental Studies on the Effects of Cyclic Freezing-Thawing, Salt Crystallization, and Thermal Shock on the Physical and Mechanical Characteristics of Selected Sandstones. Rock Mech. Rock Eng. 2015, 48, 1001-1016. [CrossRef]

23. Ruedrich, J.; Siegesmund, S. Salt and ice crystallisation in porous sandstones. Environ. Geol. 2007, 52, 225-249. [CrossRef]

24. EN 12370. Natural Stone Test Methods. Determination of Resistance to Salt Crystallization; BSI—British Standards Institution: London, UK, 1999.

25. Winkler, E.M. Stone in Architecture; Springer: Berlin/Heidelberg, Germany, 1997.

26. Suchet, P.A.; Probst, A.; Probst, J.L. Influence of acid rain on CO2 consumption by rock weathering: Local and global scales. Water Air Soil Pollut. 1995, 85, 1563-1568. [CrossRef]

27. Schiavon, N. Kaolinisation of granite in an urban environment. Environ. Geol. 2007, 52, 399-407. [CrossRef]

28. Yuan, W.; Liu, X.; Fu, Y. Chemical thermodynamics and chemical kinetics analysis of sandstone dissolution under the action of dry-wet cycles in acid and alkaline environments. Bull. Eng. Geol. Environ. 2019, 78, 793-801. [CrossRef]

29. Diko, M.L. Physicochemical and mineralogical considerations of Ediki sandstone-hosted kaolin occurrence, South West Cameroon. Int. J. Phys. Sci. 2012, 7, 501-507.

30. Malmström, M.; Banwart, S. Biotite dissolution at $25^{\circ} \mathrm{C}$ : The $\mathrm{pH}$ dependence of dissolution rate and stoichiometry. Geochim. Cosmochim. Acta 1997, 61, 2779-2799. [CrossRef]

31. Savage, D.; Bateman, K.; Hill, P.; Hughes, C.; Milodowski, A.; Pearce, J.; Rae, E.; Rochelle, C. Rate and mechanism of the reaction of silicates with cement pore fluids. Appl. Clay Sci. 1992, 7, 33-45. [CrossRef]

32. Malmström, M.; Banwart, S.; Lewenhagen, J.; Duro, L.; Bruno, J. The dissolution of biotite and chlorite at $25^{\circ} \mathrm{C}$ in the near-neutral pH region. J. Contam. Hydrol. 1996, 21, 201-213. [CrossRef]

33. SSamson, D.; Nagy, K.L.; Cotton, W.B. Transient and quasi-steady-state dissolution of biotite at $22-25^{\circ} \mathrm{C}$ in high $\mathrm{pH}$, sodium, nitrate, and aluminate solutions. Geochim. Cosmochim. Acta 2005, 69, 399-413. [CrossRef]

34. Sharvit, J.; Planer, D. Akko, the Southern Seawall. Preliminary Report. 2014. Available online: http://www.hadashot-esi.org.il/ report_detail_eng.aspx?id=10574\&mag_id=121 (accessed on 5 January 2021).

35. Mitchell, D.; Torney, C. Inform: The Use of Lime and Cement in Traditional Builings; Historic Scotland: Edinburgh, Scotland, 2015.

36. Vitruvius, P. The Ten Books on Architecture. Book II: Stone. Available online: http://www.perseus.tufts.edu/hopper/text?doc= Vitr.2\&lang=original (accessed on 3 December 2020).

37. Osborne, F.F. Rift, grain, and hardway in some pre-Cambrian granites, Quebec. Econ. Geol. 1935, 30, 540-551. [CrossRef]

38. Rivas, T.; Prieto, B.; Silva, B. Influence of rift and bedding plane on the physico-mechanical properties of granitic rocks. Implications for the deterioration of granitic monuments. Build. Environ. 2000, 35, 387-396. [CrossRef]

39. NNaghoj, M.; Youssef, N.A.R.; Maaitah, O.N. Mechanical Properties of Natural Building Stone: Jordanian Building Limestone as an Example. Jordan J. Earth Environ. Sci. 2010, 3, 37-48.

40. Israel Ministry of Environmental Protection. Reduction of Pollution from Transportation in Haifa Bay (Hebrew, Updated January 2017); Israel Ministry of Environmental Protection: Jerusalem, Israel, 2017.

41. Israel Ministry of Environmental Protection. Haifa Bay Air Quality Values (Hebrew, Updated January 2017); Israel Ministry of Environmental Protection: Jerusalem, Israel, 2017. 
42. NUMBEO. Pollution in Acre, Israel. 2020. Available online: https://www.numbeo.com/pollution/in/Acre (accessed on 30 December 2020).

43. Charola, A.E.; Pühringer, J.; Steiger, M. Gypsum: A review of its role in the deterioration of building materials. Environ. Geol. 2007, 52, 339-352. [CrossRef]

44. Sánchez, J.S.; Alves, C.A.S.; Romaní, J.R.V.; Mosquera, D.F. Origin of Gypsum-rich Coatings on Historic Buildings. Water. Air. Soil Pollut. 2009, 204, 53-68. [CrossRef]

45. Sánchez, J.S.; Romaní, J.R.V.; Alves, C. Deposition of particles on gypsum-rich coatings of historic buildings in urban and rural environments. Constr. Build. Mater. 2011, 25, 813-822. [CrossRef]

46. Schaffer, Y.; Sharvit, J.; Planer, D. Structural and conservation solutions for the treatment of the sea front walls of old Akko (Acre), Israel. In Proceedings of the SAHC2014: 9th International Conference on Structural Analysis of Historical Constructions, Mexico City, Mexico, 14-17 October 2014; pp. 1-23. 